\title{
Van Balığında (Alburnus tarichi Güldenstädt, 1814) Üreme Göçü Sırasında Oksidatif Stresin Araştırılması
}

\author{
Ahmet Regaib OĞUZ*, Necati ÖZOK, Aso Hemn OMAR, Zehra ALKAN \\ Ayşe Nur KIRAÇÇAKALI
}

Van Yüzüncü Yıl Üniversitesi, Fen Fakültesi, Biyoloji Bölümü, Van

\begin{abstract}
Öz
Van Balı̆̆ı, Türkiye'nin en büyük gölüne endemik anadrom bir türdür. Balıklar, her sene üremesini gerçekleştirmek için alkali Van Gölü’nden göle dökülen tatlı sulara göç ederler. Balık bu göç sırasında açlık, tuz ve $\mathrm{pH}$ adaptasyonu gibi farklı stres faktörlerine maruz kalır. Bu çalışmada, Van Balı̆̆ının üreme göçü öncesi ve sonrasında plazma, solungaç, karaciğer, beyin ve kas gibi dokularındaki total oksidan ve antioksidan, lipid peroksidasyon ve DNA hasarları karşılaştırıldı. Total oksidan durum (TOS) üreme öncesi gölden yakalanan balıkların karaciğer ve böbrek dokularında, total antioksidan durum (TAS) ise akarsudan yakalanan balıklarda karaciğerde, gölden yakalanan balıkların ise beyin ve böbrek dokularında yüksek olduğu bulundu $(\mathrm{P}<0.05)$. Malondialdehit (MDA) seviyelerinin akarsudan örneklenen balıkların karaciğerinde gölden örneklenen balıklarda ise böbreklerinde daha fazla olduğu belirlendi $(\mathrm{P}<0.05)$. DNA hasarının ise sadece tatlı sudan örneklenen balıkların karaciğerinde arttığı belirlendi. Sonuç olarak, Van Balığında üreme göçü sırasında karşılaşılan stres etkilerine karşı organların gösterdiği tepkiler belirlendi.
\end{abstract}

Anahtar kelimeler: Van Balığı, Oksidatif Stres, Lipid Peroksidasyon, DNA Hasarı, Alburnus tarichi.

\section{Investigation of Oxidative Stress in Van Fish (Alburnus tarichi Güldenstädt, 1814) During Reproductive Migration}

\begin{abstract}
Van Fish is an anadromous species of endemic to Turkey's largest lake. The fish migrate to the freshwater pouring from the alkaline Lake Van to the lake for the reproduction every year. Fish are exposed to different stress factors such as fasting, salt and $\mathrm{pH}$ adaptation during migration. In this study, total oxidant and antioxidant, lipid peroxidation and DNA damages in tissues such as gill, liver, plasma, brain and muscle were compared before and after reproductive migration. Total oxidant status (TOS) of the fish caught in the lake before reproduction, liver and kidney tissues, total antioxidant status (TAS), fish liver caught from freshwater, fish from the lake were observed to be high in the brain and kidney tissues $(\mathrm{P}<0.05)$. Malondialdehyde (MDA) levels were found to be higher in the liver and kidney of the fish sampled from the freshwater and lake, respectively. $(\mathrm{P}<0.05)$. DNA damage was found only in the liver of fish sampled from freshwater. As a result, the reactions of the organs against stress effects encountered during reproduction migration were determined.
\end{abstract}

Keywords: Van Fish, Oxidative stress, Lipid peroxidation, DNA damage, Alburnus tarichi.

\section{Giriş}

Reaktif oksijen türleri, aeorobik solunumun bir sonucu olarak canlılarda meydana gelir. Artan oksidanlar sonucunda oksidatif stres meydana gelir. Oksidatif stres hücrelerde protein, lipid, DNA ve diğer moleküllere zarar verebilir. Antioksidanlar, reaktif oksijen türlerinin oluşumunu ve bunların meydana getirdiği hasarı önlemek üzere görev yapan enzimlerdir [1-2]. Artan serbest radikaller aynı zamanda lipid peroksidasyonuna sebep olarak hücre membran işlevlerinin bozulmasına neden olur.

*Sorumlu yazar: ahmetoguz@yyu.edu.tr

Geliş Tarihi:13.01.2019, Kabul Tarihi: 21.01.2019 
Sonuç olarak lipid peroksidasyonunun yıkım ürünü olan malondialdehit oluşur ve lipidlerin oksidatif hasarının belirlenmesinde indikatör olarak kullanılır. Ayrıca, artan reaktif oksijen türleri hücrelerde DNA hasarına da neden olmaktadır. 8-hidroksi-2'-deoksiguanozin (8-OHdG), oksidatif baz hasar ürünü olup DNA hasarının belirlenmesinde yoğun olarak kullanılmaktadır [3].

Balıklarda oksidatif stres, pek çok faktör tarafindan etkilenir. Bunların başında sıcaklık, tuz adaptasyonu, açlık, ksenobiyotikler ve hastalıklar gelmektedir. Sıcaklık artışı bütün canlılarda metabolik aktiviteleri arttırır. Artan metabolizma ile ihtiyaç duyulan oksijen miktarı da artar ve sonuç olarak total oksidan seviyesi artar. Farklı canlı gruplarında sıcaklığa bağlı olarak oksidatif stresin arttığı bildirilmiştir [4]. Balıklarda tuz adaptasyonu sırasında pek çok fizyolojik değişim gözlenmektedir. Bunlar enerji metabolizmasının artması, iyon dengesinin ayarlanması, moleküler ve hücresel değişimler ve hormonal düzenlemelerdir. Balıklarda hem deneysel olarak oluşturulan hem de doğal ortamda gerçekleşen tuz adaptasyonu sırasında da dokularında reaktif oksijen türleri oluşarak oksidatif hasara neden olmaktadır [5-6]. Uzun süreli açlık, memelilerde olduğu gibi balıklarda da özellikle enerji metabolizmasının gerçekleştiği karaciğerde oksidatif hasara neden olmuştur [7-8]. Balıklarda farklı içeriğe sahip besinlerin de karaciğerde oksidatif durum üzerine etkili olduğu bildirilmiştir. Özellikle yüksek lipid içeriğe sahip besinler katalaz ve süperoksit dismutaz gibi antioksidan enzim seviyelerini arttırmıştır [9].

Van Balığı (Alburnus tarichi) göl suyu sıcaklığına bağlı olarak yıl içerisinde farklı derinliklerde sürüler halinde dolaşır. Üreme mevsimi olan Nisan ve Temmuz ayları arasında göle dökülen tatlı sulara göç eder. Balık, tatlı sulara girmeden önce göl suyu ve tatlı suyun karıştığı akarsu ağızlarında bekleyerek muhtemelen adaptasyon için moleküler ve hücresel değişimleri gerçekleştirir. Yoğun sürüler halinde tatlı sulara geçen balıklar dışarıdan yem almaz. Balık, tatlı su içerisinde su yılanları, kuşlar ve insanların avlanma baskısı altındadır. Ayrıca göçün gerçekleştiği akarsuların sıcaklığı ile göl suyu arasında az da olsa farklılık vardır. İyon içeriği açısından da göl suyu tatlı sulara göre oldukça zengindir [10].

Balıklardaki oksidatif stres çalışmaları, genel olarak çevresel kirleticilerin etkilerinin belirlenmesi üzerine yoğunlaşmıştır [2, 11-12]. Balıklar için büyük öneme sahip üreme göçü sırasındaki oksidatif stres çalışmaları oldukça sınırlıdır. Bu çalışmada, bölge halkı için ucuz ve önemli bir protein kaynağı olan Van Balığının üreme göçü sırasında farklı dokularındaki oksidatif stres incelenmiştir.

\section{Materyal ve Metot}

Van balıkları, Nisan ve Temmuz ayları arasında Van Gölü’nden ve göle dökülen akarsulardan (Karasu Çayı) sırasıyla uzatmalı fanyalı ağ ve serpme ağlarla yakalandı. Yakalanan balıklara anestezi işlemi uygulandıktan sonra çatal boy $(\mathrm{cm})$ ve total ağırlık (gr) ölçümleri yapıldı. Kuyruk kısmından heparin içeren enjektörler ile kanları alınan balıklar, daha sonra disekte edilerek karaciğer, solungaç, beyin, kas ve böbrek dokuları alınd. Doku örnekleri, 0.1 mM EDTA ve \% 0.1 triton X100 içeren 10 kat (v:v) Tris $\mathrm{HCl}(\mathrm{pH}: 7.8)$ ile homojenize edildi. Homojenatlar $4{ }^{\circ} \mathrm{C}$ 'de 30 dakika santrifüj edildi ve süpernatantlar analiz için kullanıldı.

Bu çalışma için Van Yüzüncü Yıl Üniversitesi Hayvan Deneyleri Yerel Etik Kurulu'ndan 25.01.2018 tarih ve 2018/01 karar sayısı ile gerekli izinler alınmıştır.

\subsection{Total antioksidan seviyeleri (TAS) ve total oksidan seviyeleri (TOS)}

Total antioksidan seviyeleri (TAS) ve total oksidan seviyeleri (TOS) hazır kitler (Rel Assay Diagnostics, Gaziantep) ile belirlendi. Ekstrakte edilen dokulara kit prosedürü uygulandı.

\subsection{Malondialdehit (MDA) seviyelerinin belirlenmesi}

MDA konsantrasyonu Jain vd. [13]'nin spektrofotometrik metoduyla ölçüldü. Doku ekstraktından sonra $0.2 \mathrm{~mL}$ süpernatant, $0.8 \mathrm{~mL}$ fosfat tamponu (pH 7.4), $0.025 \mathrm{~mL}$ butile hidroksitolüen ve $0.5 \mathrm{~mL} \% 30$ trikloroasetik asit, efendorph tüplerine alındı ve karıştırıldı. $-20^{\circ} \mathrm{C}^{\prime} \mathrm{de} 2$ saat inkübasyondan sonra, karışım 15 dakika boyunca santrifüj edildi. Daha sonra, her bir tüpe $1 \mathrm{~mL}$ süpernatan alınmış ve daha sonra $75 \mu \mathrm{L} 0.1 \mathrm{~mol}$ EDTA ve $0.25 \mathrm{~mL} \% 1$ tiyobarbutirik asit eklenmiştir. Tüpler $90^{\circ} \mathrm{C}$ de 15 dakika boyunca bir su banyosunda inkübe edildi ve oda sicaklığına soğutuldu. Tiyobarbutirik asit ile MDA'nın oluşturduğu renkli kompleksin absorbansı $532 \mathrm{~nm}$ dalga boyunda ölçüldü. 


\subsection{DNA hasarının belirlenmesi}

Ekstrakte edilen dokulardaki DNA hasar seviyeleri hazır ELISA kit (8-Hydroxy-desoxyguanosine,8OHdG ELISA Kit E1436 BT-Laboratory) kullanılarak belirlendi. Test sonucunda her kuyucuğun optik dansitesi, durdurma çözeltisi eklendikten sonra 30 dakika içinde $450 \mathrm{~nm}$ 'ye ayarlanmış bir mikroplaka okuyucu kullanılarak belirlendi.

\section{4. İstatistiksel Analiz}

Analizler sonucunda elde edilen değerler ortalama \pm standart hata olarak ifade edildi. Farklı örnekleme alanlarından ortaya çıkan değerin ikili karşılaştırmaları için t-test yapılarak farklılık ortaya konuldu. Değerler arasındaki fark 0.05 'e göre yapıldı.

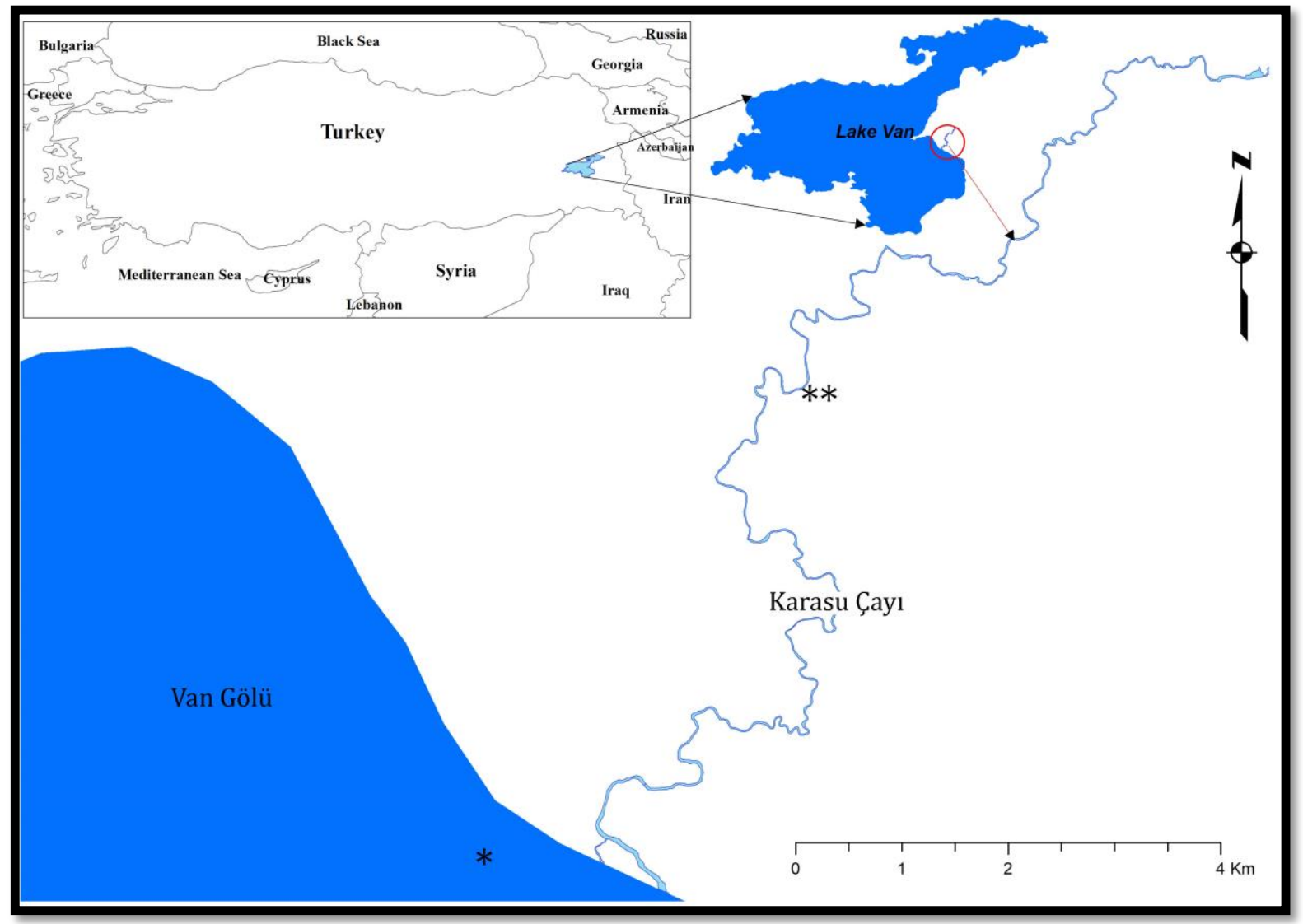

Şekil 1. Van Balığının üremesini gerçekleştirdiği Karasu Çayı. * Van Gölü ve **Karasu Çayı Örnekleme alanları.

\section{Bulgular ve Tartışma}

Balıkların üreme göçü öncesi göl suyu ve tatlı suların karıştığı alanlarda sürüler halinde hareket ettikleri gözlemlendi. Tatlı suya (Karasu çayı) da yine sürüler halinde göç ettikleri belirlendi (Şekil 2).

Tatlı sudan yakalanan balıkların sindirim kanalının genellikle boş veya boşa yakın olduğu gözlemlendi. Gölden yakalanan balıkların gonadlarında yumurta ve spermlerin bulunduğu; akarsulardan örneklenen balıkların ise yumurta ve spermini bıraktığı ve üremesini tamamlandığı belirlendi. 


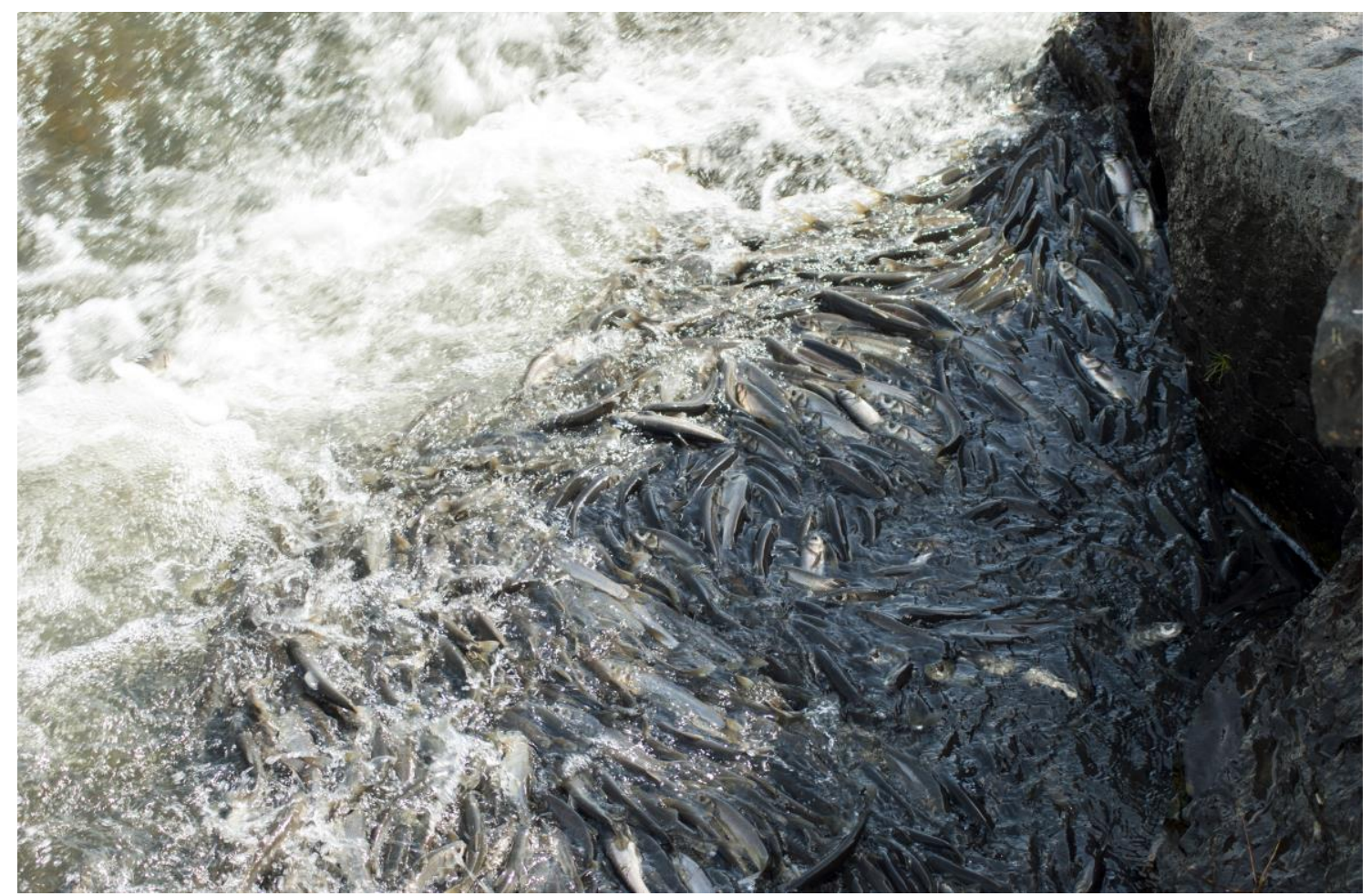

Şekil 2. Van Balığının Karasu Çayındaki üreme göçü

TOS seviyesi gölden örneklenen balıkların karaciğerinde ve akarsudan yakalanan balıkların böbreklerinde artış göstermiştir $(\mathrm{P}<0.05)$ (Şekil 3). Van Balığında üreme göçü sırasında gonad ağırlığı maksimum seviyeye ulaşır [14]. Yüksek gonadosomatik indekse sahip balıklar akarsuya giremeden önce göl ve tatlısuyun karıştı̆̆ bölgelerde zaman geçirerek adaptif değişimler geçirirler [10]. Gerekli olan enerji karaciğerden sağlanır. Tatlı suda balıkların glomerular filtrasyonu oldukça hızlıdır ve iyon kaybı minimum seviyededir. Balıklarda böbrekler tatlı sularda dilue idrar üreterek osmoregülasyonda etkin role sahiptir [15]. Bu nedenle tatl suya adapte olan balıklarda bazal metabolizmaları tuzlu suya adapte olanlara göre yüksektir. Bu çalışmada da karaciğerde ve böbreklerde oksidanların artması beklenildiği gibidir.

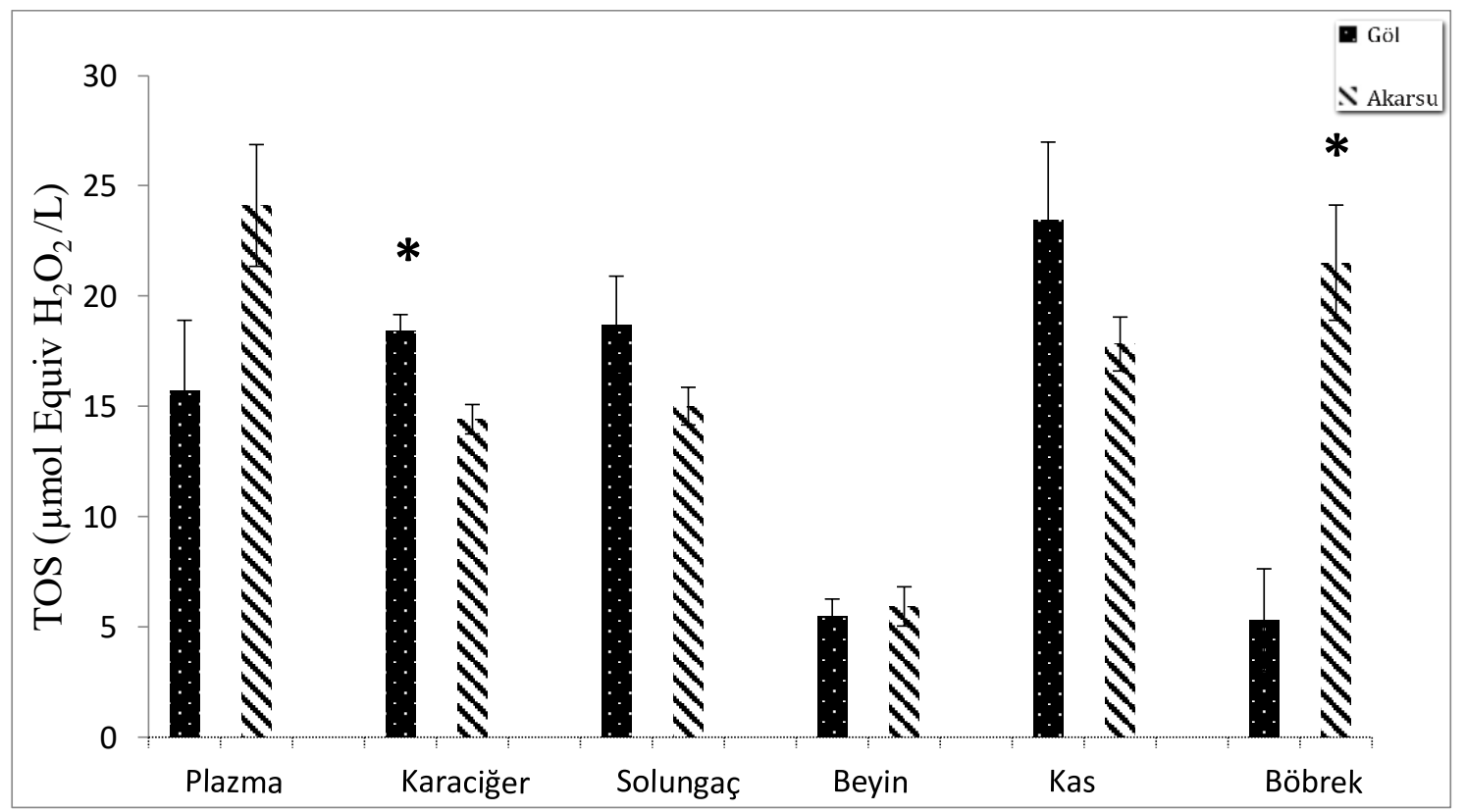

Şekil 3. Van Gölü ve tatlısu ortamlarından alınan Van Balığı dokularında total oksidan durum (TOS) seviyeleri * istatistiksel farklılığı göstermektedir $(\mathrm{P}<0.05)$. (n:7). 
Bu çalışmada, total antioksidan seviyesi karaciğerde artmış beyin ve böbrek dokularında ise azalmıştır (P<0.05) (Şekil 4). Daha önceki çalışmalarda balıklarda açlığın katalaz, süperoksit dismutaz, glutatyon peroksidaz seviyelerini arttırdığı bildirilmiştir [16-18]. Üreme göçü sırasında Van Balığının sindirim kanalının boş veya boşa yakın olduğu, dışarıdan besin almadığı belirlendi. Van Balıklarında açlık antioksidan enzim sentezini tetiklemiş olabilir.

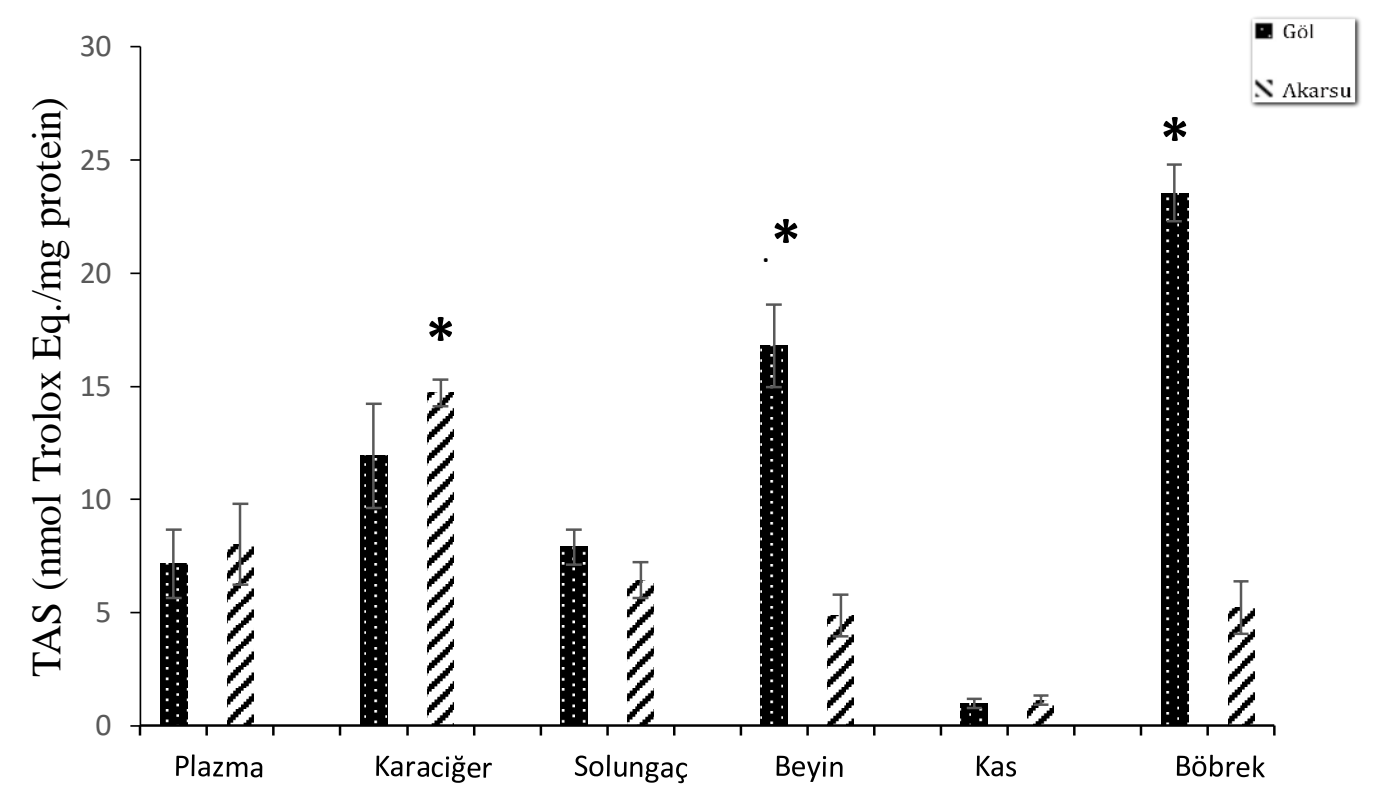

Şekil 4. Van Gölü ve tatlısu ortamlarından alınan Van Balığı dokularında total antioksidan durum (TAS) seviyeleri * istatistiksel farkl11l ğ göstermektedir $(\mathrm{P}<0.05)$. (n:7).

Lipid peroksidasyon, oksidatif stresin belirlenmesinde kullanışlı bir biyoindikatördür. Tatlısuya giren balıkların karaciğer MDA seviyeleri önemli oranda artış göstermiş $(\mathrm{P}<0.05)$, diğer dokularda ise bir farklılık bulunmamıştır $(\mathrm{P}>0.05)$ (Şekil 5). Üreme göçü sırasında Van Balıklarının dışarıdan besin almadığı, sindirim kanalının boş olduğu belirlenmiştir. Balıklarda açlığın karaciğerde oksidatif strese neden olduğu sonuç olarak MDA metabolitini arttırdığı pek çok çalışmada da belirtilmiştir [16, 19-20]. Acipenser naccarii'nin deneysel olarak artan tuz adaptasyonunda karaciğer MDA seviyesinde herhangi bir değişim bulunmamıştır [21-22]. Sonuç olarak, açlığın, karaciğer MDA seviyesi üzerine direkt etkisinin olduğu söylenebilir.

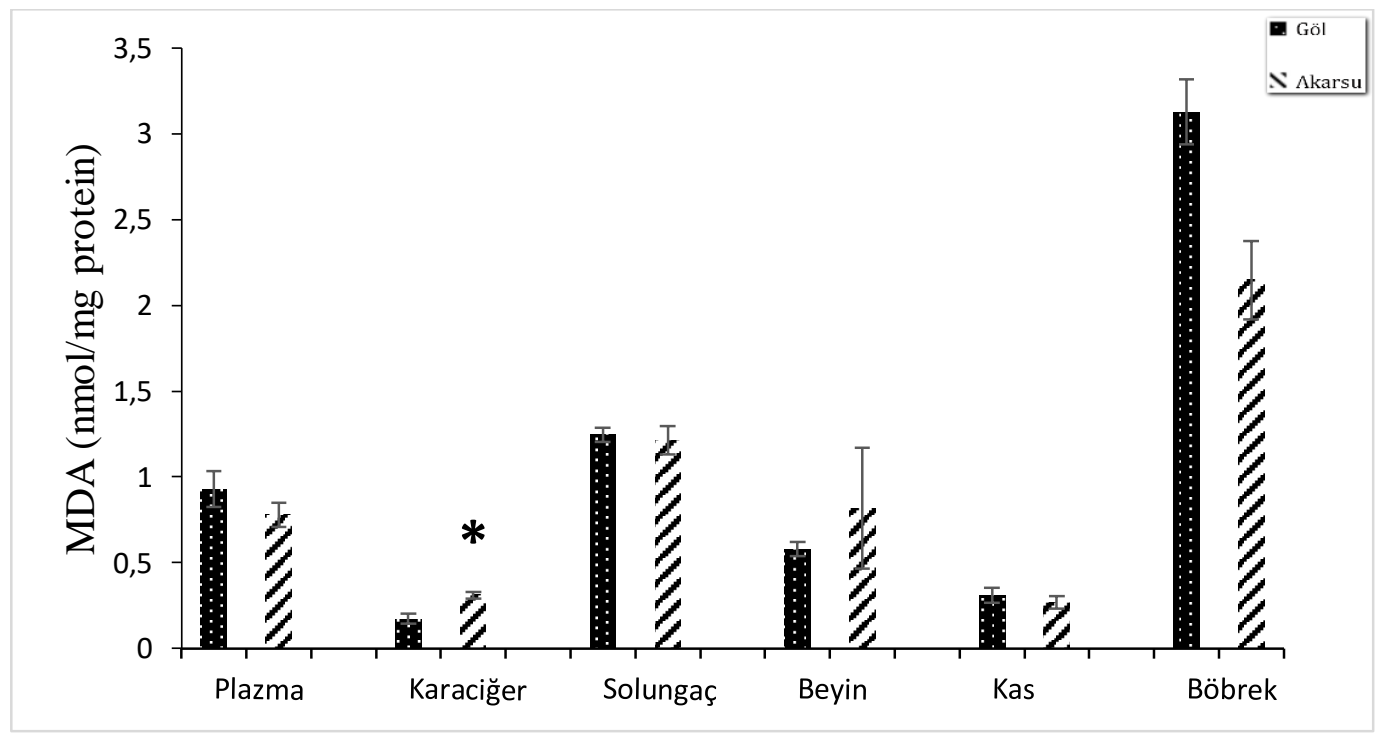

Şekil 5. Van Gölü ve tatlısu ortamlarından alınan Van Balığı dokularında malondialdehit (MDA) seviyeleri * istatistiksel farklılığı göstermektedir $(\mathrm{P}<0.05)$. (n:7). 
DNA hasarı dokulardan sadece tatlısudan örneklenen karaciğerde artış göstermiştir $(\mathrm{P}<0.05)$ (Şekil 6). Genetik materyal üzerinde meydana gelen tüm değişimler DNA hasarı olarak bilinir. Serbest radikallerde hücrelerde DNA hasarına neden olur. Bu çalışmada, serbest radikaller, antioksidan enzim sentezini ve DNA hasarını karaciğer dokusunda arttırmış olabilir [23].

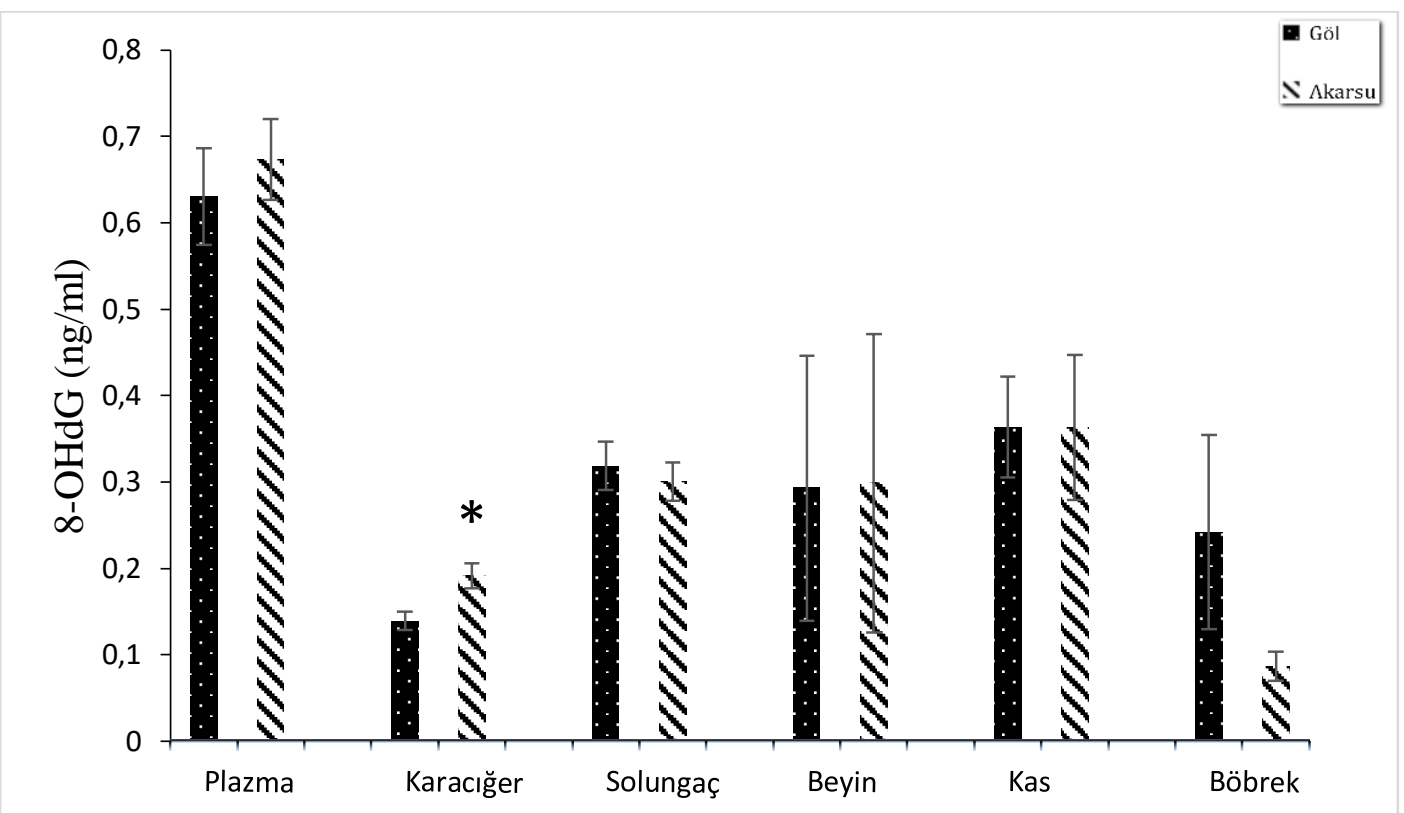

Şekil 6. Van Gölü ve tatlısu ortamlarından alınan Van Balığı dokularında 8-hidroksi-2'-deoksiguanozin (8OHdG) seviyeleri * istatistiksel farklılığı göstermektedir $(\mathrm{P}<0.05)$. (n:7).

Solungaçlar balıklarda osmoregülasyonda rol oynayan temel dokulardandır. Bu çalışmada, solungaçların oksidatif stresten etkilenmeme nedeni; dokunun moleküler ve hücresel adaptasyon kabiliyetinin yüksek olmasından kaynaklanmış olabilir. Van Balıklarında, daha önce yapılan çalışmalarda solungaç dokusundaki değişimler histolojik ve immünohistokimyasal olarak belirlenmiştir. Üreme göçü sırasında tatlı sulardaki klorid ve mukus hücrelerindeki değişimler ve lamellar füzyon değişimleri gözlemlenmiştir [24-25]. Bu çalışmada da balık solungacındaki hücresel değişimler çevresel etkilerin solungaçta meydana gelebilecek oksidatif hasarın etkisini azaltmış olabilir.

Pasifik Somonunda üreme göçü sırasında en fazla etkilenen dokulardan biri kas dokusudur (beyaz kas, kırmızı kas, kalp kası) [5, 26]. Bu çalışmada ise üreme göçünün kas dokusu üzerine etkisi belirlenemedi $(\mathrm{P}<0.05)$. Pasifik Somon balığı ve diğer göç eden balıklarda uzun mesafeli göçler (1300 km) gerçekleşirken, Van Balığının üreme mesafesi ise daha kısadır (Şekil 1).

\section{Sonuç ve Öneriler}

$\mathrm{Bu}$ çalışma sonucunda elde edilen bulgular, üreme göçünün Van Balığı'nda önemli biyokimyasal değişikliklere neden olduğunu göstermiştir. Üreme göçü sırasında artan metabolik aktivite balıkların farklı dokularında reaktif oksijen türlerinin artmasına yol açmıştır. Artan reaktif oksijen türleri, reaktif oksijen türleri ve antioksidanlar arasında dengenin bozulmasına ve oksidatif stresin oluşumuna neden olmuştur. Sonuç olarak üreme göçü sırasında en fazla etkilenen dokunun Van Balığında karaciğer olduğu belirlendi. Daha önceki çalışmalarda diğer dokularda gözlemlenen hasarın bu çalışmada daha az görülmesi, üreme göç süresinin ve üreme göç mesafesinin daha kısa olmasından kaynaklanmış olabilir.

\section{Teşekkür}

Bu çalışmanın yayınlanmasında beni teşvik ve motive eden biyoloji bölümü ve eczacıllk fakültesi ögretim üyelerine teşekkür ederim. 


\section{Kaynaklar}

[1] Lushchak V.I. 2011. Environmentally induced oxidative stress in aquatic animals. Aquatic Toxicology, 101 (1): 13-30.

[2] Birnie-Gauvin K., Costantini D., Cooke S.J., Willmore W.G. 2017. A comparative and evolutionary approach to oxidative stress in fish: a review. Fish and Fisheries, 18 (5): 928-942.

[3] Kasai H. 1997. Analysis of a form of oxidative DNA damage, 8-hydroxy-2'-deoxyguanosine, as a marker of cellular oxidative stress during carcinogenesis. Mutation Research/Reviews in Mutation Research, 387 (3): 147-163.

[4] Almroth B.C., Asker N., Wassmur B., Rosengren M., Jutfelt F., Gräns A., Sundell K., Axelsson M., Sturve J. 2015. Warmer water temperature results in oxidative damage in an Antarctic fish, the bald notothen. Journal of Experimental Marine Biology and Ecology, 468: 130-137.

[5] Wilson S.M., Taylor J.J., Mackie T.A., Patterson D.A., Cooke S.J., Willmore W.G. 2014. Oxidative stress in Pacific salmon (Oncorhynchus spp.) during spawning migration. Physiological and Biochemical Zoology, 87 (2): 346-352.

[6] Liu Y., Wang W.N., Wang A.L., Wang J.M., Sun R.Y. 2007. Effects of dietary vitamin E supplementation on antioxidant enzyme activities in Litopenaeus vannamei (Boone, 1931) exposed to acute salinity changes. Aquaculture, 265 (1-4): 351-358.

[7] Bayir A., Sirkecioglu A.N., Bayir M., Haliloglu H.I., Kocaman E.M., Aras N.M. 2011. Metabolic responses to prolonged starvation, food restriction, and refeeding in the brown trout, Salmo trutta: oxidative stress and antioxidant defenses. Comparative Biochemistry and Physiology Part B: Biochemistry and Molecular Biology, 159 (4): 191-196.

[8] Morales A.E., Pérez-Jiménez A., Hidalgo M.C., Abellán E., Cardenete G. 2004. Oxidative stress and antioxidant defenses after prolonged starvation in Dentex dentex liver. Comparative Biochemistry and Physiology Part C: Toxicology \& Pharmacology, 139 (1): 153-161.

[9] Rueda-Jasso R., Conceiçao L.E., Dias J., De Coen W., Gomes E., Rees J.F., Sorgeloos P. 2004. Effect of dietary non-protein energy levels on condition and oxidative status of Senegalese sole (Solea senegalensis) juveniles. Aquaculture, 231 (1-4): 417-433.

[10] Danulat E, Selçuk B. 1992. Life history and enviromental conditions of the anadromous Chalcalburnus tarichi (Cyprinidae) in the highly alkaline Lake Van, Eastern Anatolia, Turkey. Arch Hidrobiol., 126 (1): 105-125.

[11] Kelly K.A., Havrilla C.M., Brady T.C., Abramo K.H., Levin E.D. 1998. Oxidative stress in toxicology: established mammalian and emerging piscine model systems. Environmental health perspectives, 106 (7): 375-384.

[12] Slaninova A., Smutna M., Modra H., Svobodova Z. 2009. REVIEWS Oxidative stress in fish induced by pesticides. Neuroendocrinology Letters, 30 (1): 2.

[13] Jain S.K., McVie R., Duett J., Herbst J.J. 1989. Erythrocyte membrane lipid peroxidation and glycosylated hemoglobin in diabetes. Diabetes, 38 (12): 1539-1543.

[14] Ünal G., Çetinkaya O., Elp M. 1999. Histological investigation of gonad development of Chalcalburnus tarichi (P., 1811). Turkish Journal of Zoology, 23 (EK1): 329-338.

[15] Marshall W.S., Grosell M. 2006. Ion transport, osmoregulation, and acid-base balance. The physiology of fishes, 3: 177-230.

[16] Pascual P., Pedrajas J.R., Toribio F., López-Barea J., Peinado J. 2003. Effect of food deprivation on oxidative stress biomarkers in fish (Sparus aurata). Chemico-biological interactions, 145 (2): 191-199.

[17] Nam Y.K., Cho Y.S., Choi B.N., Kim K.H., Kim S.K., Kim D.S. 2005. Alteration of antioxidant enzymes at the mRNA level during short-term starvation of rockbream Oplegnathus fasciatus. Fisheries Science, 71 (6): 1385-1387.

[18] Welker T.L., Congleton J.L. 2005. Oxidative stress in migrating spring Chinook salmon smolts of hatchery origin: changes in vitamin $\mathrm{E}$ and lipid peroxidation. Transactions of the American Fisheries Society, 134 (6): 1499-1508.

[19] Hidalgo M.C., Exposito A., Palma J.M., de la Higuera M. 2002. Oxidative stress generated by dietary Zn-deficiency: studies in rainbow trout (Oncorhynchus mykiss). The international journal of biochemistry \& cell biology, 34 (2): 183-193. 
[20] Varju M., Müller T., Bokor Z., Żarski D., Mézes M., Balogh K. 2018. The effects of excessive starvation on antioxidant defence and lipid peroxidation in intensively reared, commercial-size pikeperch (Sander lucioperca L.). The Egyptian Journal of Aquatic Research, 44 (4): 349-352.

[21] Martinez-Alvarez R.M., Hidalgo M.C., Domezain A., Morales A.E., García-Gallego M., Sanz A. 2002. Physiological changes of sturgeon Acipenser naccarii caused by increasing environmental salinity. Journal of experimental biology, 205 (23): 3699-3706.

[22] Martínez-Álvarez R.M., Morales A.E., Sanz A. 2005. Antioxidant defenses in fish: biotic and abiotic factors. Reviews in Fish Biology and fisheries, 15 (1-2): 75-88.

[23] Barzilai A., Yamamoto, K.I. 2004. DNA damage responses to oxidative stress. DNA Repair, 3 (8-9): 1109-1115.

[24] Oğuz A.R. 2015. Histological changes in the gill epithelium of endemic Lake Van Fish (Chalcalburnus tarichi) during migration from alkaline water to freshwater, North-Western Journal of Zoology 11 (1): 51-57.

[25] Oğuz A.R. 2013. Environmental regulation of mitochondria-rich cells in Chalcalburnus tarichi (Pallas, 1811) during reproductive migration. The Journal of membrane biology, 246 (3): 183188.

[26] Miller K.M., Schulze A.D., Ginther N., Li S., Patterson D.A., Farrell A.P., Hinch S.G. 2009. Salmon spawning migration: metabolic shifts and environmental triggers. Comparative Biochemistry and Physiology Part D: Genomics and Proteomics, 4 (2): 75-89. 